\title{
Vegetation-climate interactions in the warm mid-Cretaceous
}

\author{
J. Zhou ${ }^{1}$, C. J. Poulsen ${ }^{1}$, N. Rosenbloom ${ }^{2}$, C. Shields ${ }^{2}$, and B. Briegleb ${ }^{2}$ \\ ${ }^{1}$ Department of Earth and Environmental Sciences, University of Michigan, USA \\ ${ }^{2}$ National Center for Atmospheric Research, Boulder, Colorado, USA \\ Correspondence to: J. Zhou (zotsing @umich.edu)
}

Received: 23 August 2011 - Published in Clim. Past Discuss.: 7 September 2011

Revised: 30 January 2012 - Accepted: 2 February 2012 - Published: 16 March 2012

\begin{abstract}
Vegetation-climate interactions are thought to have amplified polar warmth during past warm periods. Here, we explore the vegetation-climate interactions in the mid-Cretaceous using a fully coupled ocean-atmosphere general circulation model with a dynamic vegetation component. We run simulations with $1 \mathrm{x}, 10 \mathrm{x}$ and $16 \mathrm{x}$ pre-industrial atmospheric $\mathrm{CO}_{2}$. Results show that forests expand from mid-latitudes to high latitudes as $\mathrm{CO}_{2}$ increases from $1 \mathrm{x}$ to $10 \mathrm{x}$ and $16 \mathrm{x}$, mainly due to the $\mathrm{CO}_{2}$-induced warming. This expansion of mid-to-high latitude forests are largely supported by the distribution of mid-Cretaceous fossil woods and coal deposits. Globally, the presence of vegetation increases mean annual temperature and precipitation by $0.9^{\circ} \mathrm{C}$ and $0.11 \mathrm{~mm} \mathrm{day}^{-1}$ relative to bare ground. High-latitude warming induced by the presence of vegetation $\left(\sim 1.9^{\circ} \mathrm{C}\right)$ is less than half of that reported in previous studies. The weaker warming here is mainly due to less pronounced albedo feedbacks, and to a less extent, reduced poleward heat transport via weakening of the meridional overturning circulation. Our results suggest that other mechanisms in addition to high atmospheric $\mathrm{CO}_{2}$ and high-latitude vegetation are required to maintain the polar warmth.
\end{abstract}

\section{Introduction}

The mid-Cretaceous $(\sim 100 \mathrm{Ma})$ was a period of extreme polar warmth. Paleoclimate proxies indicate that mean annual temperature were as high as $20^{\circ} \mathrm{C}$ and $13^{\circ} \mathrm{C}$ over polar ocean and land (Bice et al., 2003; Jenkyns et al., 2004; Spicer et al., 2002, 2008). The cause of global warmth is widely accepted to be caused by high atmospheric $\mathrm{CO}_{2}$ levels (Barron and Washington, 1985) resulting from volcanic outgassing.
However, simulations of Cretaceous climate using general circulation models (GCMs) with high atmospheric $\mathrm{CO}_{2}$ predict polar temperatures that are too cool (Barron et al., 1995; Poulsen et al., 1999, 2004; Spicer et al., 2008) challenging our understanding of greenhouse climate.

Several hypotheses have been proposed to reconcile this high-latitude model-data discrepancy including enhanced poleward heat transport via strengthening of atmospheric or oceanic circulation (e.g., Covey and Barron, 1988; Farrel, 1990; Korty et al., 2008), increased local radiative forcing through high-latitude cloud feedbacks (e.g., Abbot and Tziperman, 2008; Sloan and Pollard, 1998; Kump and Pollard, 2008), high atmospheric methane levels (Bice et al., 2006) and high-latitude forests (Deconto et al., 2000; Otto-Bliesner and Upchurch, 1997; Upchurch et al., 1998). Of these mechanisms only the existence of high-latitude forests is directly supported by observations in the geological records (e.g., Herman and Spicer, 1996; Falcon-Lang et al., 2001; Spicer and Parrish, 1986; Spicer et al., 1993).

Previous studies have reported that the expansion of forests into polar regions in the Late Cretaceous may have warmed high-latitude regions by $4-7{ }^{\circ} \mathrm{C}$ (Deconto et al., 2000; Otto-Bliesner and Upchurch, 1997; Upchurch et al., 1998). The warming is mainly attributed to a reduction in surface albedo due to the masking of snow via forests and melting of sea ice via transfer of heat from vegetated land to ocean. The role of vegetation feedbacks on polar warming has not been examined for the mid-Cretaceous when $\mathrm{CO}_{2}$ levels were thought to have been higher. In addition, previous Late Cretaceous modelling studies coupled atmospheric general circulation models (AGCMs) to mixedlayer ocean models that do not allow for dynamic ocean feedbacks. Paleoclimate modelling of Cenozoic intervals 
has demonstrated that vegetation-induced climate change can influence the strength of the ocean meridional overturning circulation (MOC) (Brovkin, 2002; Brovkin et al., 2009; Ganopolski et al., 1998; Lohmann et al., 2006). Of possible relevance to Cretaceous polar warmth, Lohmann et al. (2006) report that the prescribed present to warm late-Miocene vegetation changes strengthen the North Atlantic MOC by more than 3 times, leading to a warming over the mid-to-high latitude North Atlantic by up to $8^{\circ} \mathrm{C}$. Furthermore, previous studies investigated the Cretaceous vegetation-climate interactions using prescribed vegetation changes (Otto-Bliesner and Upchurch, 1997; Upchurch et al., 1998) or an equilibrium vegetation model (Deconto et al., 2000), which do not allow realistic transient climate-vegetation interactions as in dynamic global vegetation models (Peng, 2000).

In view of the limitations of these earlier studies, we re-examine the vegetation-climate interactions in the Cretaceous under high atmospheric $\mathrm{CO}_{2}$ using a fully coupled ocean-atmosphere GCM with a dynamic vegetation component (CCSM3). This study addresses two main questions: (1) Can CCSM3 simulate the mid-Cretaceous vegetation distribution, and if so, at what atmospheric $\mathrm{CO}_{2}$ levels? (2) How does the simulated vegetation affect mid-Cretaceous climate? We first examine the climate control on vegetation by comparing the vegetation pattern with low (1x) and high (10x and 16x) atmospheric $\mathrm{CO}_{2}$. We then investigate the impact of vegetation on climate by comparing a simulation with the maximum simulated vegetation mass to a simulation without vegetation.

\section{Methods}

Cretaceous simulations were completed with NCAR's Community Climate System Model version 3 (CCSM3), a fully coupled GCM with dynamic global vegetation (Collins et al., 2006; Levis et al., 2004). CCSM3 was run in a T31x3 configuration, with a $\mathrm{T} 31$ spectral truncation $\left(3.75^{\circ} \times 3.75^{\circ}\right)$, 26-level atmosphere component model (Community Atmospheric Model) coupled to a nominal $3^{\circ}(\sim 400 \mathrm{~km}$ in the zonal direction at the equator), 25-level ocean component model (Parallel Ocean Program). To increase grid cell density around the Arctic area and promote interbasin exchange, the grid North pole is displaced to $75^{\circ} \mathrm{N}, 120^{\circ} \mathrm{E}$ in our simulations. The land surface model (Community Land Model) and dynamic global vegetation model (CLM-DGVM) are set to the same horizontal resolution as atmosphere; the sea ice component model (Community Sea Ice Model) has the same horizontal resolution as the ocean. The simulated presentday climate with this low-resolution configuration is comparable to the higher-resolution (i.e., T42x1 and $\mathrm{T} 85 \times 1$ ) results and modern observation (Yeager et al., 2006). Due to its relatively low computational cost, this economical configuration is considered a good approach for paleoclimate studies (e.g., Kiehl and Shields, 2005).
Vegetation distribution in CLM-DGVM is largely determined by solar radiation, air temperature, soil moisture and atmospheric $\mathrm{CO}_{2}$ concentration (Bonan and Levis, 2006). For example, the survival and establishment of vegetation are constrained by bioclimatic parameters including monthly air temperature, growing degree days (GDD) and mean annual precipitation (Table 1). CLM-DGVM classifies vegetation as patches of plant function types (PFTs) (Levis et al., 2004). A PFT represents the average individual for a group of species that share similar physiological and morphological characteristics. All PFTs can co-exist in a grid cell's soil-covered portion when climate allows. CLM-DGVM calculates vegetation dynamics including allocation, biomass turnover, mortality, aboveground competition, fire and establishment yearly. Levis et al. (2004) provide a detailed description of vegetation dynamics. Vegetation biogeography and structure is also updated yearly. Canopy phenology is updated daily. The communication between CLM-DGVM and the atmosphere model is achieved through exchanges of energy, momentum, and moisture every $20 \mathrm{~min}$ (Levis et al., 2004). Our version of CLM-DGVM does not simulate transient changes in atmospheric $\mathrm{CO}_{2}$.

Eight PFTs are defined in this study, with one herbaceous PFT ( $\mathrm{C}_{3}$ grasses) and seven woody PFTs (trees) (Table 1). We exclude $\mathrm{C}_{4}$ grasses in this study because $\mathrm{C}_{4}$ grasses did not become ecologically important until the Early-middle Miocene (Cerling et al., 1993; Jacobs et al., 1999). Though the origin of $\mathrm{C}_{3}$ grassland is no earlier than the Late Cretaceous (Jacobs et al., 1999), we include $\mathrm{C}_{3}$ grasses for two reasons: (1) CLM-DGVM does not have a PFT representing shrubs, therefore, shrublands are often simulated as desert or grasslands (Bonan et al., 2003); and (2) the fossil record suggested a widespread distribution of herbaceous vegetation during the mid-Cretaceous (Spicer et al., 1993).

To determine the equilibrium vegetation distribution corresponding to the mid-Cretaceous warm climate, we conducted three simulations implementing CLM-DGVM, namely, 1xDGVM, 10xDGVM and 16xDGVM (Table 2). An additional experiment $(10 \times \mathrm{BG})$ was run with land surface prescribed as bare ground. Atmospheric $\mathrm{CO}_{2}$ concentration was set to $1 \mathrm{x}, 10 \mathrm{x}$ or $16 \mathrm{x}$ pre-industrial levels. $16 \mathrm{x}$ pre-industrial levels $\mathrm{CO}_{2}$ likely falls in the upper limit of the estimated mid-Cretaceous atmospheric $\mathrm{CO}_{2}$ levels (see summary in Bice and Norris, 2002). DGVM simulates physiological changes in photosynthesis and stomatal conductance due to changes in the ambient partial pressure of $\mathrm{CO}_{2}$. However, in these simulations, we used the default physiological $p \mathrm{CO}_{2}$ (355 ppmv) for three reasons: (1) modern studies show that high $p \mathrm{CO}_{2}$ does not necessarily enhance plant productivity (e.g., Körner, 2003). Nutrients (e.g., nitrogen and phosphorus) appear to become a limiting factor for photosynthesis with increasing $p \mathrm{CO}_{2}$. (2) $\mathrm{CO}_{2}$ physiological effects likely vary significantly from species to species. Whether the modern empirical equation is applicable to ancient plants is questionable. And, (3) our sensitivity test shows that the 
Table 1. Bioclimatic parameters for survival and establishment of plant functional type (PFT). Adapted from Table 1 in Bonan et al. (2003).

\begin{tabular}{lrrrrr}
\hline PFT & $T_{\mathrm{c}, \min }\left({ }^{\circ} \mathrm{C}\right)$ & $T_{\mathrm{c}, \max }\left({ }^{\circ} \mathrm{C}\right)$ & $T_{\mathrm{hs}}\left({ }^{\circ} \mathrm{C}\right)$ & $\mathrm{GDD}\left({ }^{\circ} \mathrm{C}\right.$ day $)$ & $P\left(\mathrm{~mm} \mathrm{yr}^{-1}\right)$ \\
\hline Tropical broadleaf evergreen & 15.5 & $\mathrm{NA}$ & $\mathrm{NA}$ & $\mathrm{NA}$ & 100 \\
Tropical broadleaf deciduous & 15.5 & $\mathrm{NA}$ & $\mathrm{NA}$ & $\mathrm{NA}$ & 100 \\
Temperate needleleaf evergreen & -2.0 & 22.0 & $\mathrm{NA}$ & 900 & 100 \\
Temperate broadleaf evergreen & 3.0 & 18.8 & $\mathrm{NA}$ & 1200 & 100 \\
Temperate broadleaf deciduous & -17.0 & 15.5 & $\mathrm{NA}$ & 1200 & 100 \\
Boreal needleleaf evergreen & -32.5 & -2.0 & 23 & 600 & 100 \\
Boreal deciduous & $\mathrm{NA}$ & -2.0 & 23 & 350 & 100 \\
$\mathrm{C}_{3}$ grasses & -17.0 & $\mathrm{NA}$ & $\mathrm{NA}$ & 0 & 100 \\
\hline
\end{tabular}

All values are based on 20-yr running mean. $T_{\mathrm{c}, \min }=$ coldest minimum monthly air temperature for survival, $T_{\mathrm{c}, \text { max }}=$ warmest minimum monthly air temperature for establishment, $T_{\mathrm{hs}}=$ heat stress air temperature for survival, GDD $\mathrm{GDin}_{\min }=$ minimum annual growing degree-days above $5^{\circ} \mathrm{C}$, which is the sum of all positive values of difference between average daily temperature and $5^{\circ} \mathrm{C}$ in one year, $P_{\min }=$ minimum annual precipitation for establishment. The only difference between our defined PFTs and the ones in Bonan et al. (2003) is our treatment of $T_{\mathrm{c}, \max }$ for $\mathrm{C}_{3}$ grasses, to allow $\mathrm{C}_{3}$ grasses to expand over the $\mathrm{C}_{4}$ grass range, we eliminate the maximum temperature threshold for $\mathrm{C}_{3}$ grasses.

model cannot handle physiological $p \mathrm{CO}_{2}$ as high as $10 \mathrm{x} / 16 \mathrm{x}$ pre-industrial levels. All experiments were run with a reduced solar constant (99\% of modern) (Gough, 1981) and present day orbital parameters. The model geography and topography were based on mid-Cretaceous (100 Ma) reconstructions from PALEOMAP project (Scotese, 2001). Because sea level was at highstand, global land area is $18.6 \%$ less than present day. Following Poulsen et al. (2003), we applied an age-depth relationship to reconstruct bathymetry for the deep ocean regions with known magnetic lineations (Barron, 1987). Elsewhere, deep-ocean depths were set to $5300 \mathrm{~m}$. River runoff is routed to the ocean via a river transport model (Branstetter, 2001). All experiments were initiated using zonal ocean temperatures and salinity from a warm Late Cretaceous simulation (Otto-Bliesner et al., 2002). Vegetation was initialized from a $300 \mathrm{yr}$ integration of a Cretaceous CAM3-DGVM simulation with 10x preindustrial $\mathrm{CO}_{2}$ levels. Levis et al. (2004) report that global vegetation distribution approaches equilibrium in a few hundred years in CLM-DGVM. Each of our Cretaceous experiments was run in excess of $1600 \mathrm{yr}$ (Table 2). The changes of global vegetated land cover fraction are statistically insignificant $\left(\sim 0.1 \%\right.$ century $\left.^{-1}\right)$ by the end of simulations. The drifts in simulated global mean ocean temperature over the last $200 \mathrm{yr}$ are also small (on the order of $0.1^{\circ} \mathrm{C}_{\text {century }}{ }^{-1}$ ) for all experiments.

\section{Results}

\subsection{Response of vegetation to $\mathrm{CO}_{2}$ levels}

\subsubsection{Simulated surface temperature and precipitation}

The increase of atmospheric $\mathrm{CO}_{2}$ leads to an increase in global annual mean surface temperature from 13.6 to 24.0 and $25.6^{\circ} \mathrm{C}$ in the $1 \times$ DGVM, 10xDGVM and $16 x D G V M$ experiments, respectively (Table 2 ). Continental surface tem- peratures increase by up to $\sim 10^{\circ} \mathrm{C}$ at low latitudes and $29^{\circ} \mathrm{C}$ at high latitudes as a result of increasing $\mathrm{CO}_{2}$ from 1 to $16 x$ PAL (Fig. 1a). Consistent with the increase in surface temperature, global annual mean precipitation increases from $2.90 \mathrm{~mm} \mathrm{day}^{-1}$ in the $1 \mathrm{xDGVM}$ experiment to 3.47 and $3.56 \mathrm{~mm} \mathrm{day}^{-1}$ in the 10xDGVM and 16xDGVM experiments (Table 2). The increase in continental precipitation between 1xDGVM and 16xDGVM experiments is up to $1.8(\sim 33 \%)$ and $1.9(\sim 150 \%)$ mm day $^{-1}$ at low and mid-to-high latitudes. In contrast, the continental precipitation decreases by $\sim 0.3 \mathrm{~mm}_{\text {day }^{-1}}(\sim 20 \%)$ in the southern subtropical latitudes ( 20-30 $\mathrm{S})$ (Fig. 1b).

\subsubsection{Simulated global vegetation distribution}

In the 1xDGVM experiment, the tropics, subtropics, midlatitudes and high latitudes are dominated by evergreen trees, grasses, mixture of evergreen and deciduous trees and polar desert, respectively (Fig. 2a-c). In the high $\mathrm{CO}_{2}$ experiments, trees (especially deciduous) and grasses advance into the northern high latitudes and Antarctica (Fig. 2di). In the northern high latitudes $\left(60-90^{\circ} \mathrm{N}\right)$, average fractional tree cover over the soil-covered land increases from $0.7 \%$ in the $1 \times$ DGVM experiment to $61 \%$ (10xDGVM) and $59 \%(16 \mathrm{xDGVM})$. The change in tree cover at the southern high latitudes $\left(60-90^{\circ} \mathrm{S}\right)$ is slightly less than the northern high latitudes, increasing from $4 \%$ (1xDGVM) to $51 \%(10 \mathrm{xDGVM})$ and $43 \%(16 \mathrm{xDGVM})$. In contrast, tree cover at low latitudes $\left(30^{\circ} \mathrm{S}-30^{\circ} \mathrm{N}\right)$ decreases from $60 \%$ (1xDGVM) to $54 \%(10 x D G V M)$ and $50 \%$ (16xDGVM). As a result of the poleward expansion of trees and grasses, area-weighted global vegetation cover increases from $56 \%$ (1xDGVM) to $85 \%$ (10xDGVM and 16xDGVM). Global net primary production (NPP), which is equal to the net gain of carbon through photosynthesis and respiration, is estimated to be $61.8{\mathrm{PgC} \mathrm{yr}^{-1}}^{-1}$ in the $1 \mathrm{xDGVM}$ experiment, comparable to observational estimates of present-day NPP (Schlesinger, 1997). Due to the increase in global vegetation 
Table 2. Mid-Cretaceous CCSM3 experiments and global annual mean surface temperature (SAT) and precipitation.

\begin{tabular}{lrlrrr}
\hline Experiment & $\begin{array}{r}\text { Atm. } \\
\mathrm{CO}_{2}(\mathrm{ppmv})\end{array}$ & Vegetation & $\begin{array}{r}\text { Integration } \\
(\text { year })\end{array}$ & $\begin{array}{r}\text { SAT } \\
\left({ }^{\circ} \mathrm{C}\right)\end{array}$ & $\begin{array}{r}\text { Precipitation } \\
\left(\mathrm{mm} \mathrm{day}^{-1}\right)\end{array}$ \\
\hline 1xDGVM & 280 & DGVM & 2125 & 13.6 & 2.90 \\
10xBG & 2800 & Bare ground & 1626 & 23.1 & 3.36 \\
10xDGVM & 2800 & DGVM & 1637 & 24.0 & 3.47 \\
16xDGVM & 4480 & DGVM & 1615 & 25.6 & 3.56 \\
\hline
\end{tabular}
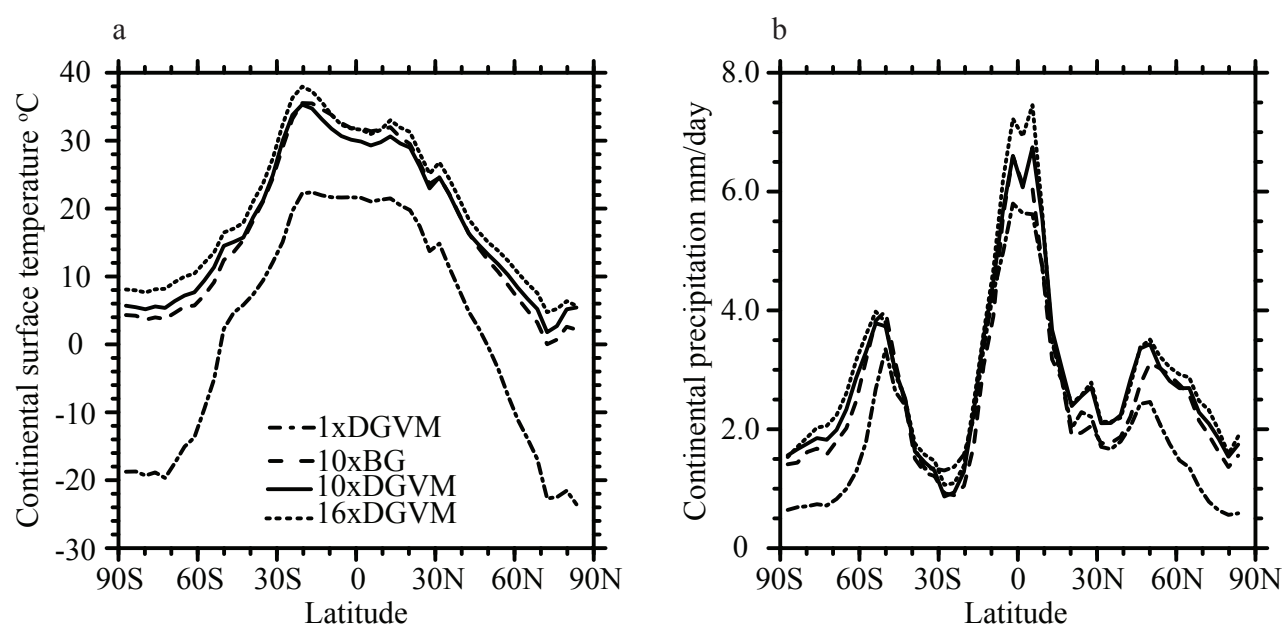

Fig. 1. Zonal-average annual mean continental surface temperature $\left({ }^{\circ} \mathrm{C}\right)(\mathbf{a})$; and precipitation $\left(\mathrm{mm}\right.$ day $\left.{ }^{-1}\right)(\mathbf{b})$ for the $1 \mathrm{xDGVM}(\mathrm{black}$ dash-dot line), 10xBG (black dashed line), 10xDGVM (black solid line) and 16xDGVM (black dotted line) experiments, respectively.

cover, NPP increases by $13.5 \mathrm{PgC} \mathrm{yr}^{-1}(21.8 \%)$ in the 10xDGVM experiment and $10.9 \mathrm{PgC} \mathrm{yr}^{-1}(17.6 \%)$ in the 16xDGVM experiment relative to the 1xDGVM experiment.

The large-scale changes in vegetation distribution are linked to changes in surface temperatures and precipitation. The expansion of trees and grasses at mid- and high latitudes in the two high $\mathrm{CO}_{2}$ experiments is mainly due to $\mathrm{CO}_{2}$ induced warming (Fig. 1a). In the $1 \times$ DGVM experiment, GDD (i.e., annual growing degree days above $5^{\circ} \mathrm{C}$ ), which measures the accumulation of growing season warmth in a year, is largely less than $350^{\circ} \mathrm{C}$ day at high latitudes inhibiting tree growth (Table 1) and the minimum monthly temperature is lower than $-17^{\circ} \mathrm{C}$ prohibiting grass growth (Table 1). In contrast, in the high $\mathrm{CO}_{2}$ experiments, GDD is generally greater than $1200{ }^{\circ} \mathrm{C}$ day except in the cold Siberian interior due to the large increase in surface temperature (Fig. 1a), providing a sufficient growing season for all tree PFTs to thrive (Table 1). In addition, the minimum monthly temperature exceeds $-17^{\circ} \mathrm{C}$, allowing the establishment of temperate trees and grasses. The retreat of subtropical grasses in the Southern Hemisphere in the two high $\mathrm{CO}_{2}$ experiments is caused by a decrease in precipitation associated with enhanced subtropical subsidence. The decrease in low-latitude evergreen tree cover and increase in deciduous tree cover with higher
$\mathrm{CO}_{2}$ are also associated with the decrease in precipitation (Fig. 1b).

The poleward expansion of trees at mid-to-high latitudes under high atmospheric $\mathrm{CO}_{2}$ matches the fossil data reasonably well (Fig. 3). The simulated dominant woody PFTs at mid- and high-latitude North America, Greenland, coastal Eurasia, New Zealand, Australia and coastal Antarctica are supported by fossil woods and coal deposits (Beerling et al., 1999; Falcon-Lang et al., 2001; Herman and Spicer, 1996; Price et al., 1997). In contrast, the simulated predominant woody PFTs in the tropical South America and Africa appears inconsistent with the presence of fossil elaterate assemblages, a unique palynoflora assemblage indicating arid climate (Dino et al., 1999). The dense tropical trees simulated in our model are similar to the simulated midCretaceous vegetation pattern by the University of Sheffield dynamic global vegetation model or FOAM-LPJ (Beerling et al., 1999; Donnadieu et al., 2009). 
a $1 \mathrm{xDGVM}$
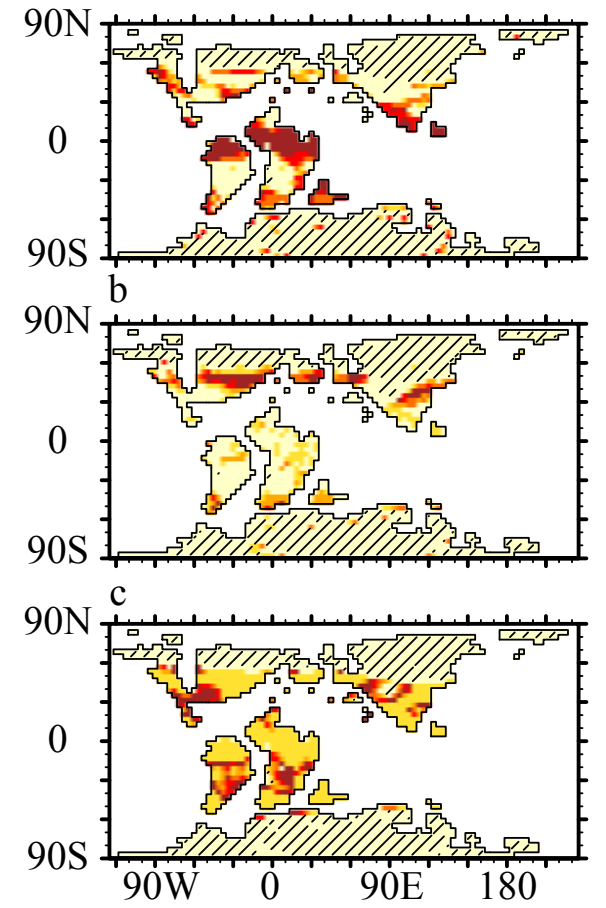

d 10xDGVM Evergreen trees

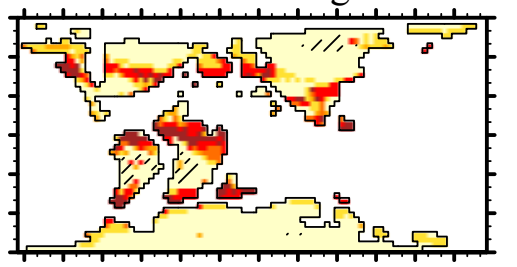

e
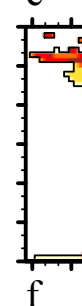

$\mathrm{f}$

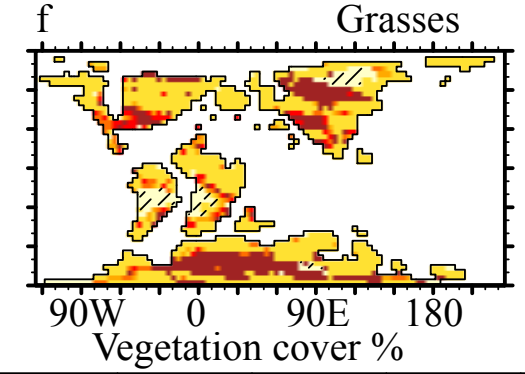

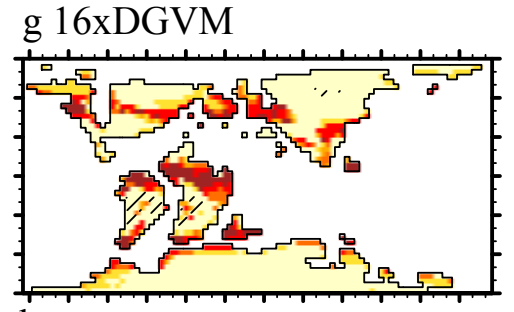

$\mathrm{h}$

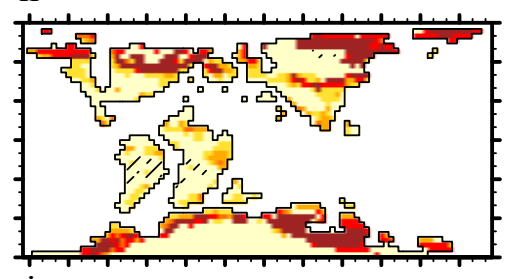

$\mathrm{i}$

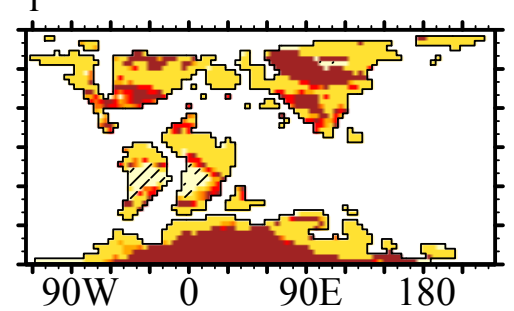

5

25

45

65

85

Fig. 2. Global distribution of evergreen trees (a), (d), (g), deciduous trees (b), (e), (h) and grasses (c), (f), (i) (\%) for the $1 \times D G V M$, 10xDGVM, and 16xDGVM experiments, respectively. Land area with $<10 \%$ vegetation cover, which is defined as desert, is shaded. Note, hereafter, continental outlines delimit area with $>50 \%$ land cover. Evergreen trees include tropical and temperate broadleaf evergreen, and temperate and boreal needleleaf evergreen. Deciduous trees include tropical and temperate broadleaf deciduous and boreal deciduous.

\subsection{Impact of vegetation on mid-Cretaceous climate}

\subsubsection{Land surface response}

The presence of vegetation in the 10xDGVM experiment increases mid-Cretaceous global surface temperature by $0.9^{\circ} \mathrm{C}$ (Table 2). Changes in surface temperature show significant spatial (Fig. 4b) and seasonal variations (Fig. 5a, f and k). High-latitude forested areas experience annual warming of $2.3^{\circ} \mathrm{C}$ with early summer warming of up to $4.0^{\circ} \mathrm{C}$ (Figs. $4 \mathrm{~b}$ and 5a). In contrast, low-latitude forested areas undergo year-round cooling (Figs. 4b and 5f). Mid-latitude Northern Hemisphere surface temperatures increase during the cold seasons and decrease during the warm seasons (Fig. 5k). Changes in surface temperatures over ocean are generally less than $1{ }^{\circ} \mathrm{C}$ at low latitudes and up to $3{ }^{\circ} \mathrm{C}$ at high latitudes (Fig. $4 \mathrm{~b}$ ). The maximum increase in surface temperature $\left(>5^{\circ} \mathrm{C}\right)$ occurs in the mid-latitude North Pacific, and is caused by the poleward shift of western boundary currents (explained in Sect. 3.2.3).

The changes in land surface temperature can be explained by the net effect of vegetation-induced changes in latent heat fluxes and surface absorbed solar radiation. The former results from changes in evapotranspiration (Fig. 6a); the latter is mainly due to changes in surface albedo (Fig. 6b) and low-cloud cover (Fig. 6c). As a result of canopy evapotranspiration, the total annual mean evapotranspiration over land increases by $0.38 \mathrm{~mm} \mathrm{day}^{-1}(22.7 \%)$ in the $10 x \mathrm{xGVM}$ experiment relative to the 10xBG experiment (Fig. 6a). And the increase $\left(>1.0 \mathrm{~mm} \mathrm{day}^{-1}\right)$ is most significant over the low-to-mid latitude evergreen forests. In contrast, the annual mean land surface albedo decreases by $0.04(\sim 20 \%)$ in the 10xDGVM experiment (Fig. $6 \mathrm{~b}$ and Table 3), due to the darkening of land surface via forests, and to a less extent via reduced snow cover. The reduction (up to 0.2 ) is most pronounced over mid-to-high latitude deciduous forests through snow-masking (Fig. 6b). Seasonally, over highlatitude forests, the net surface radiation (i.e., the difference between surface absorbed solar radiation and net upward longwave radiation) increases by $\sim 24 \mathrm{~W} \mathrm{~m}^{-2}$ due to the large gain in surface absorbed solar radiation $\left(>31 \mathrm{~W} \mathrm{~m}^{-2}\right)$ during late spring and early summer (Fig. 5c), which greatly exceeds increases in latent heat fluxes (Fig. 5b), leading to significant warming (Fig. 5a). The increases in surface absorbed solar radiation are due to (1) decreases in surface 
Table 3. Global and high-latitude annual mean climatic variables in the 10xBG and 10xDGVM experiments.

\begin{tabular}{|c|c|c|c|}
\hline Variable/Experiment & $10 \times B G$ & 10xDGVM & 10xDGVM-10xBG \\
\hline SAT (land, $60-90^{\circ} \mathrm{N},{ }^{\circ} \mathrm{C}$ ) & 4.4 & 6.3 & 1.9 \\
\hline SAT (ocean, $60-90^{\circ} \mathrm{N},{ }^{\circ} \mathrm{C}$ ) & 8.1 & 10.0 & 1.9 \\
\hline SAT (land, $60-90^{\circ} \mathrm{S},{ }^{\circ} \mathrm{C}$ ) & 4.7 & 6.4 & 1.7 \\
\hline SAT (ocean, $60-90^{\circ} \mathrm{S},{ }^{\circ} \mathrm{C}$ ) & 11.0 & 12.3 & 1.3 \\
\hline Snow fraction (land, $60-90^{\circ} \mathrm{N}$ ) & 0.12 & 0.09 & -0.03 \\
\hline Snow fraction (land, $60-90^{\circ} \mathrm{S}$ ) & 0.14 & 0.10 & -0.04 \\
\hline Polar sea ice fraction & 0.005 & 0.002 & -0.003 \\
\hline Surface albedo (land) & 0.203 & 0.163 & -0.04 \\
\hline Surface albedo (land, $60-90^{\circ} \mathrm{N}$ ) & 0.273 & 0.216 & -0.057 \\
\hline Surface albedo (land, $60-90^{\circ} \mathrm{S}$ ) & 0.304 & 0.242 & -0.062 \\
\hline Surface $\mathrm{LW} \downarrow$ (ocean, $\mathrm{W} \mathrm{m}^{-2}$ ) & 396.7 & 404.0 & 7.3 \\
\hline Latent heat fluxes $\uparrow\left(\mathrm{W} \mathrm{m}^{-2}\right)$ & 97.1 & 100.5 & 3.4 \\
\hline Latent heat fluxes $\uparrow$ (land, $\mathrm{W} \mathrm{m}^{-2}$ ) & 48.8 & 59.9 & 11.1 \\
\hline Precipitable water $\left(\mathrm{kg} \mathrm{m}^{-2}\right)$ & 37.8 & 41.1 & 3.3 \\
\hline Precipitation (land, $\mathrm{mm} \mathrm{day}^{-1}$ ) & 2.69 & 2.95 & 0.26 \\
\hline Snow (land, mm day ${ }^{-1}$ ) & 0.12 & 0.10 & -0.02 \\
\hline Precipitation (ocean, mm day ${ }^{-1}$ ) & 3.57 & 3.64 & 0.07 \\
\hline Evapotranspiration (land, $\mathrm{mm} \mathrm{day}^{-1}$ ) & 1.69 & 2.07 & 0.38 \\
\hline MOC (Northern Hemisphere, Sv) & 21.4 & 16.9 & -4.5 \\
\hline MOC (Southern Hemisphere, Sv) & 9.3 & 8.3 & -1.0 \\
\hline OHT (Northern Hemisphere, PW) & 1.84 & 1.61 & -0.23 \\
\hline OHT (Southern Hemisphere, PW) & 1.16 & 1.09 & -0.07 \\
\hline
\end{tabular}

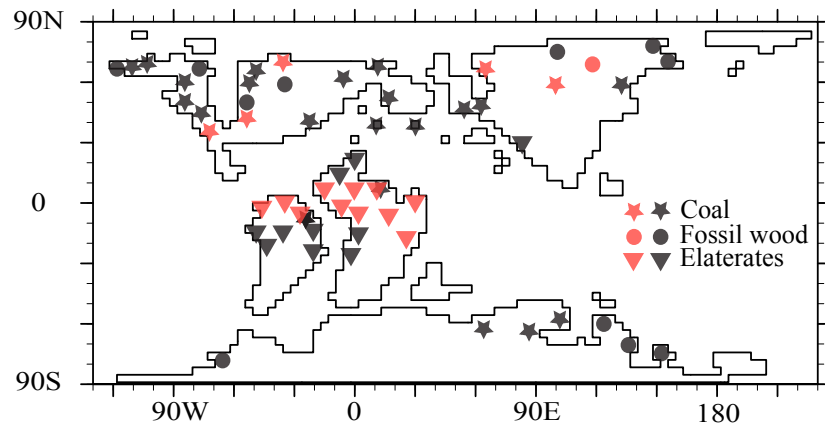

Fig. 3. Distribution of mid-Cretaceous vegetation inferred from fossil wood, pollen of Elaterate assemblages and coal deposits and comparison with simulated vegetation. Fossil wood (solid circle) and coal deposits (solid star) are indicators of high-productivity forests; fossil pollen of Elaterates assemblages (down triangle) indicates dry climate and/or mangrove swamps and savannah (Dino et al., 1999; Ziegler et al., 2003). Paleofloral data is adapted from Beerling et al. (1999), Dino et al. (1999), Falcon-Lang et al. (2001), Herman and Spicer (1996) and Price et al. (1997). The shading of symbols shows agreement between the simulated vegetation in the 10xDGVM experiment and paleofaunal data. Black indicates that the model simulates the observed faunal type; red indicates that it does not. The model-data comparison (not shown) is nearly identical for the 16xDGVM experiment. reflected solar radiation associated with the reduction in surface albedo (Fig. 5d), and (2) increases in incoming solar radiation associated with reduced low cloud cover (Fig. 6c). The decreases in low cloud cover are linked to the reduced boundary layer relative humidity with increased temperatures. In contrast, over low-latitude forests, increases in latent heat fluxes are up to $31(26) \mathrm{W} \mathrm{m}^{-2}$ greater than increases in surface absorbed solar radiation in the Northern (Southern) Hemisphere (Fig. $5 \mathrm{~g}$ and h) leading to significant cooling (Fig. 5f). The increases in absorbed solar radiation are significantly smaller than the surface albedo feedback (Fig. 5i), because low-latitude forest evapotranspiration leads to denser low cloud cover (Fig. 6c) and, thus, offsets the surface albedo feedback by reducing incoming solar radiation at the surface (Fig. 5j). Over the northern mid-latitude forests, the increases in latent heat fluxes are up to $35 \mathrm{~W} \mathrm{~m}^{-2}$ greater than increases in absorbed solar radiation during summer (Fig. 51 and $\mathrm{m}$ ) leading to summer cooling (Fig. 5k).

Unlike over land, changes in surface albedo are negligible over ocean except the northern Eurasian coastal area (Table 3 and Fig. 6b). The large-scale background warming over ocean results from the increase in downwelling longwave radiation $\left(7.3 \mathrm{~W} \mathrm{~m}^{-2}\right)$ (Table 3 ) associated with elevated atmospheric water vapour content (correlation $>0.7$ ). Warming over the southern South Atlantic and Tethys Ocean, the equatorial and northern mid-latitude Pacific Ocean, and the Western Interior Seaway is also enhanced by positive cloud 

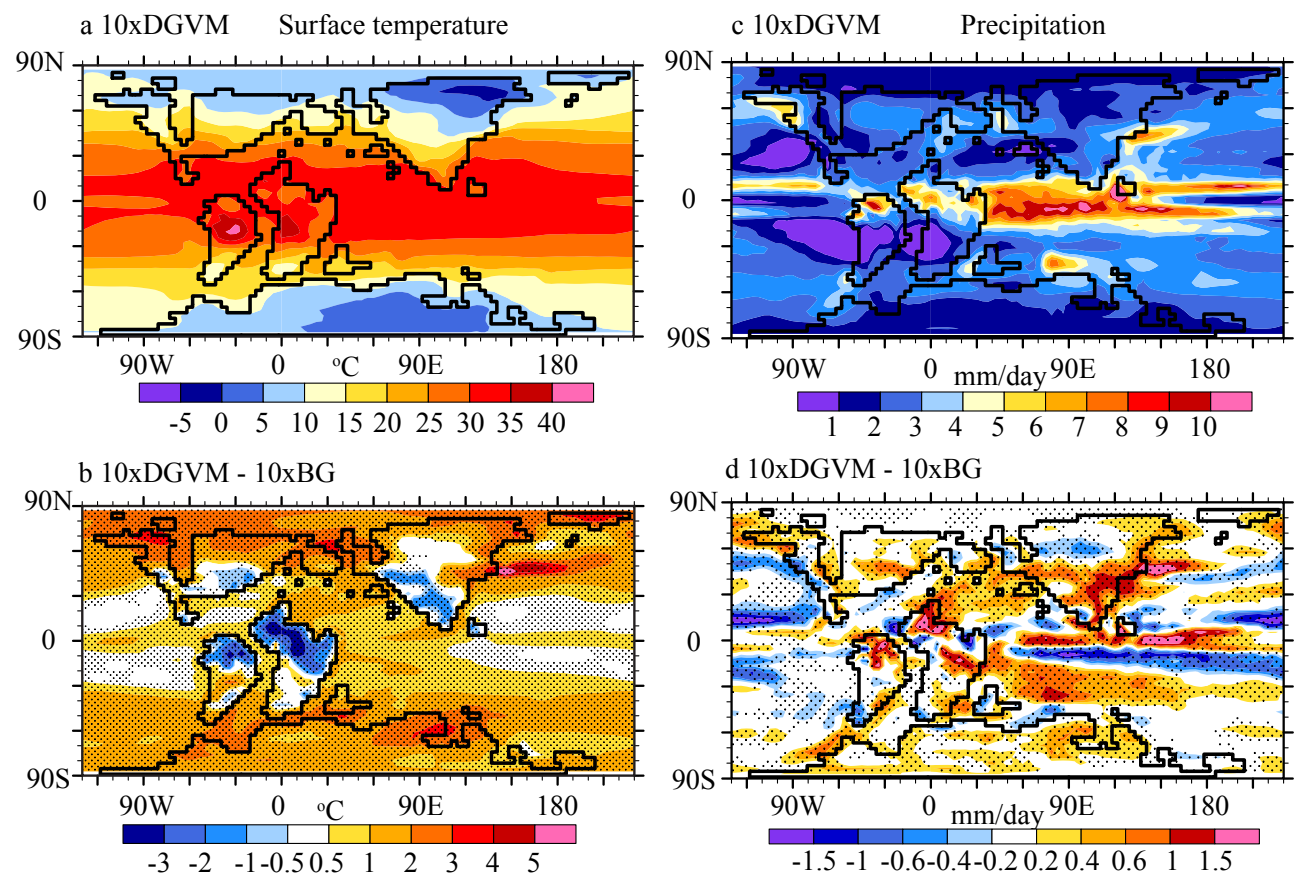

Fig. 4. Mean annual surface temperature $\left({ }^{\circ} \mathrm{C}\right)$ and precipitation $\left(\mathrm{mm} \mathrm{day}^{-1}\right)$ for $(\mathbf{a}, \mathbf{c}) 10 x \mathrm{xGVM}$ experiment; and $(\mathbf{b}, \mathbf{d})$ 10xDGVM-10xBG experiments. In $(\mathbf{b}, \mathbf{d})$, the differences exceed $95 \%$ confidence level are shaded.

radiative forcing due to reduced low cloud cover (Fig. 6c). In contrast, warming over the subtropical Pacific Ocean is suppressed by negative cloud radiative forcing due to increased low cloud cover.

\subsubsection{Precipitation response}

From a global perspective, the presence of vegetation slightly intensifies the mid-Cretaceous hydrological cycle (Table 3). As a result of the increases in the surface temperature and evapotranspiration, the global precipitable water (i.e., vertically integrated specific humidity) and precipitation increases by $3.3 \mathrm{~kg} \mathrm{~m}^{-2}(8.7 \%)$ and $0.11 \mathrm{~mm} \mathrm{day}^{-1}(3.3 \%)$, respectively. In contrast, snowfall decreases by $0.02 \mathrm{~mm}$ day $^{-1}(17 \%)$ over land. The increases in precipitation are more pronounced over land $\left(0.26 \mathrm{~mm} \mathrm{day}^{-1}, 9.7 \%\right)$ than over ocean $\left(0.07 \mathrm{~mm} \mathrm{day}^{-1}, 2.0 \%\right)$. Due to enhanced precipitation, the freshwater flux into the high-latitude North and South Pacific Ocean increases by $0.05 \mathrm{~Sv}(15.2 \%)$ and $0.03 \mathrm{~Sv}(11.5 \%)$, respectively.

The presence of vegetation leads to significant regional changes in precipitation, though the large-scale precipitation pattern remains unchanged (Fig. 4d). The most significant regional changes $\left(>1.0 \mathrm{~mm} \mathrm{day}^{-1}\right)$ occur over the low-to-mid latitude forests, intertropical convergence zones (ITCZ) and mid-latitude Western Pacific. The increases in continental precipitation are mainly due to the enhanced recycling of water via canopy evapotranspiration, with a point-to-point correlation larger than 0.6 over most areas.
In contrast, the changes in precipitation over ocean mainly reflect changes in large-scale atmospheric circulation, as shown by the changes in zonal-average annual mean meridional streamfunction (Fig. 7a). The Hadley cells weaken by $3.2 \times 10^{9} \mathrm{~kg} \mathrm{~s}^{-1}(3 \%)$ and $6.3 \times 10^{9} \mathrm{~kg} \mathrm{~s}^{-1}(7 \%)$ in the Northern and Southern Hemisphere, respectively, due to the reduced equator-to-pole temperature gradient. In addition, the ascending branches of the Hadley cells contract equatorward (from $\sim 16.7^{\circ} \mathrm{N} / \mathrm{S}$ to $13.0^{\circ} \mathrm{N} / \mathrm{S}$ ). The equatorward contraction in each hemisphere mainly occurs during winter and spring seasons when the Hadley cell expands to the other hemisphere (not shown). The weakening and contraction of Hadley cells cause anomalous ascending motion at equatorial latitudes $\left(\sim 5^{\circ} \mathrm{S}-5^{\circ} \mathrm{N}\right)$ and $\sim 20-40^{\circ} \mathrm{N} /{ }^{\circ} \mathrm{S}$ and anomalous subsidence at $\sim 10-20^{\circ} \mathrm{N} /{ }^{\circ} \mathrm{S}$. As a result, precipitation increases at $\sim 5^{\circ} \mathrm{S}-5^{\circ} \mathrm{N}$ and $20-40^{\circ} \mathrm{N} /{ }^{\circ} \mathrm{S}$ and decreases at $\sim 10-20^{\circ} \mathrm{N} /{ }^{\circ} \mathrm{S}$. The increase in precipitation at mid-latitude North Pacific is associated with warming due to a poleward shift of the western boundary currents.

\subsubsection{Ocean circulation response}

The reduction in the equator-to-pole temperature gradient in the 10xDGVM experiment leads to a decrease in zonal wind strength. As shown in Fig. $7 \mathrm{~b}$, the maximum zonal-mean wind stress over the Pacific Ocean decreases by $0.02 \mathrm{~N} \mathrm{~m}^{-2}(\sim 13 \%)$ in the Southern Hemisphere and $0.03 \mathrm{~N} \mathrm{~m}^{-2}(\sim 20 \%)$ in the Northern Hemisphere. As a result, the maximum intensity of the subtropical gyres 

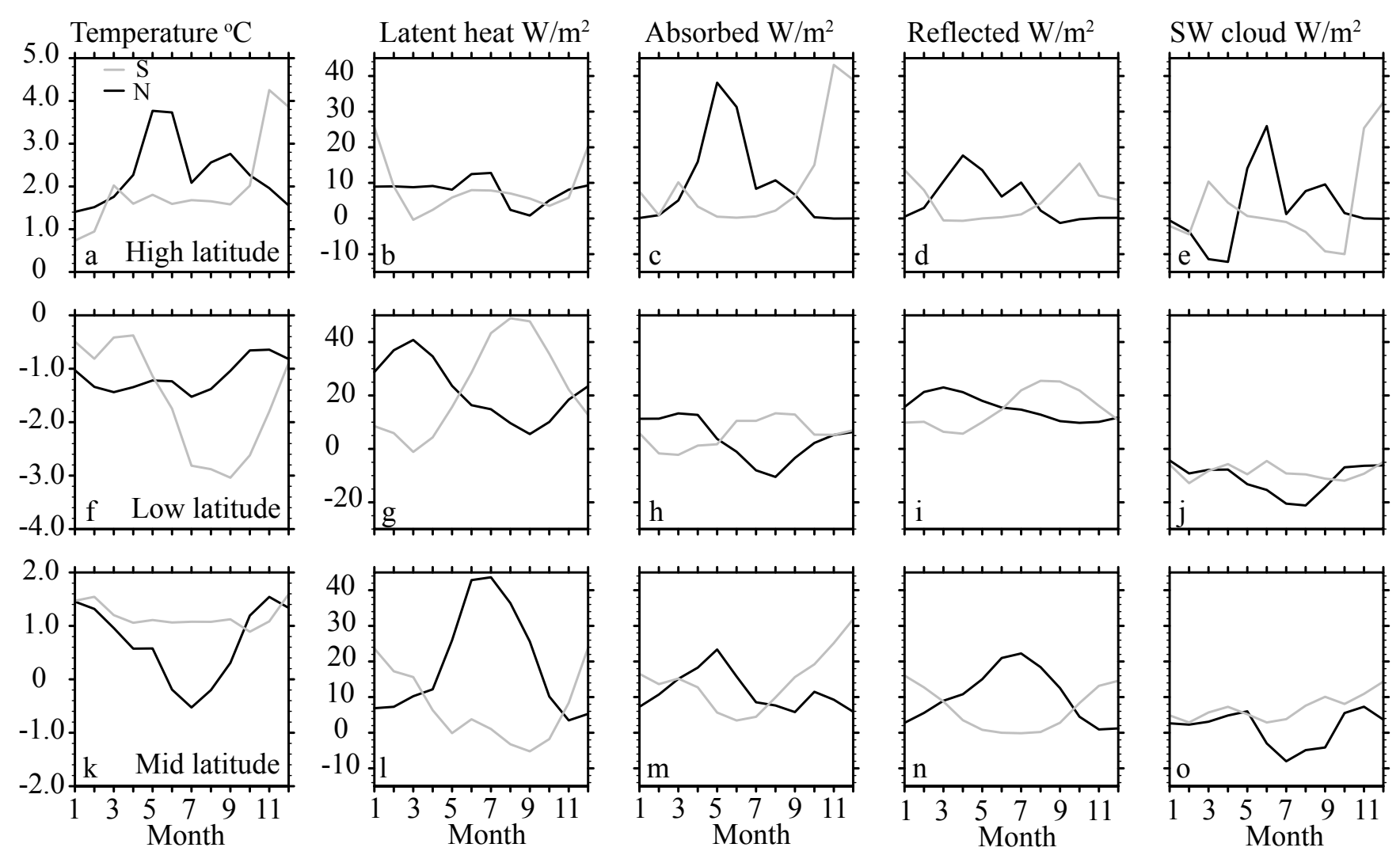

Fig. 5. Annual cycles of surface temperature $\left({ }^{\circ} \mathrm{C}\right)$, latent heat fluxes $\left(\mathrm{W} \mathrm{m}^{-2}\right)$, surface absorbed solar radiation $\left(\mathrm{W} \mathrm{m}{ }^{-2}\right)$, surface reflected solar radiation $\left(\mathrm{W} \mathrm{m}^{-2}\right)$, surface shortwave cloud forcing $\left(\mathrm{W} \mathrm{m}^{-2}\right)$ over the high-latitude forests $(\mathbf{a}-\mathbf{e})$, low-latitude forests $(\mathbf{f}-\mathbf{j})$ and midlatitude forests $(\mathbf{k}-\mathbf{o})$ for 10xDGVM-10xBG experiments. Solid black lines denote changes in the Northern Hemisphere and grey lines denote changes in the Southern Hemisphere. Low, mid and high latitudes are defined as $30^{\circ} \mathrm{S}-30^{\circ} \mathrm{N}, 30-50^{\circ} \mathrm{S} /{ }^{\circ} \mathrm{N}$ and $60-90^{\circ} \mathrm{S} /{ }^{\circ} \mathrm{N}$, respectively.

decreases by $7.9 \mathrm{~Sv}(10 \%)$ from $77.1 \mathrm{~Sv}(10 \mathrm{xBG})$ to $69.2 \mathrm{~Sv}$ (10xDGVM) in the Northern Hemisphere and by $14.0 \mathrm{~Sv}$ (13.3\%) from 105.4 Sv (10xBG) to 91.4 Sv (10xDGVM) in the Southern Hemisphere. In addition, the mean position of the maximum wind stress shifts poleward by a grid cell $\left(3.75^{\circ}\right)$ from $50.1^{\circ} \mathrm{N}$ to $53.8^{\circ} \mathrm{N}$ in the Northern Hemisphere. Consistent with this poleward shift in wind stress, the western boundary current shifts from $\sim 43^{\circ} \mathrm{N}$ in the $10 \mathrm{xBG}$ experiment to $\sim 46^{\circ} \mathrm{N}$ in the $10 \mathrm{xDGVM}$ experiment in the western North Pacific. This poleward displacement of warm, saline subtropical water leads to the significant increase in temperature $\left(>5^{\circ} \mathrm{C}\right)$ (Fig. $\left.4 \mathrm{~b}\right)$ and salinity ( $>2 \mathrm{PSU}$ ) at $\sim 45^{\circ} \mathrm{N}$.

Vegetation also weakens the intensity of global MOC, though the pattern of MOC remains the same (with deep water mainly formed in the northern Pacific Ocean). As shown in Fig. 8, the maximum magnitude of MOC decreases by $1.0 \mathrm{~Sv}(\sim 11 \%)$ from $9.3 \mathrm{~Sv}$ in the $10 \mathrm{xBG}$ experiment to $8.3 \mathrm{~Sv}$ in the 10xDGVM experiment in the Southern hemisphere and decreases by $4.5 \mathrm{~Sv}(\sim 21 \%)$ from $21.4 \mathrm{~Sv}$ in the $10 \mathrm{xBG}$ experiment to $16.9 \mathrm{~Sv}$ in the $10 \mathrm{xDGVM}$ exper- iment in the Northern hemisphere. This decrease is $0.8 \mathrm{~Sv}$ larger than $\mathrm{CO}_{2}$-induced decrease between the 10xDGVM and $1 x D G V M(20.6 \mathrm{~Sv})$ experiments. The slight weakening of MOC in the Southern Hemisphere is caused by warming (Fig. 4b) and freshening through enhanced precipitation (Fig. 4d) of the high-latitude South Pacific. In addition to the freshening via enhanced precipitation, the poleward migration of the low-salinity subpolar front associated with the poleward shift of the western boundary currents, also contributes to the decrease in seawater salinity at the highlatitude North Pacific. As a result, deep water formation along the Northeast coast of Asia vanishes and MOC slows down in the Northern Hemisphere. In response to the weakening of MOC, poleward oceanic heat transport decreases by $0.07 \mathrm{PW}(\sim 6 \%)$ in the Southern Hemisphere and 0.23 PW $(\sim 13 \%)$ in the Northern Hemisphere (Table 3$)$. This decrease in poleward heat transport diminishes the warming over the high-latitude Pacific Ocean $\left(\sim 70^{\circ} \mathrm{S} /{ }^{\circ} \mathrm{N}\right)$ (Fig. $\left.4 \mathrm{~b}\right)$. 


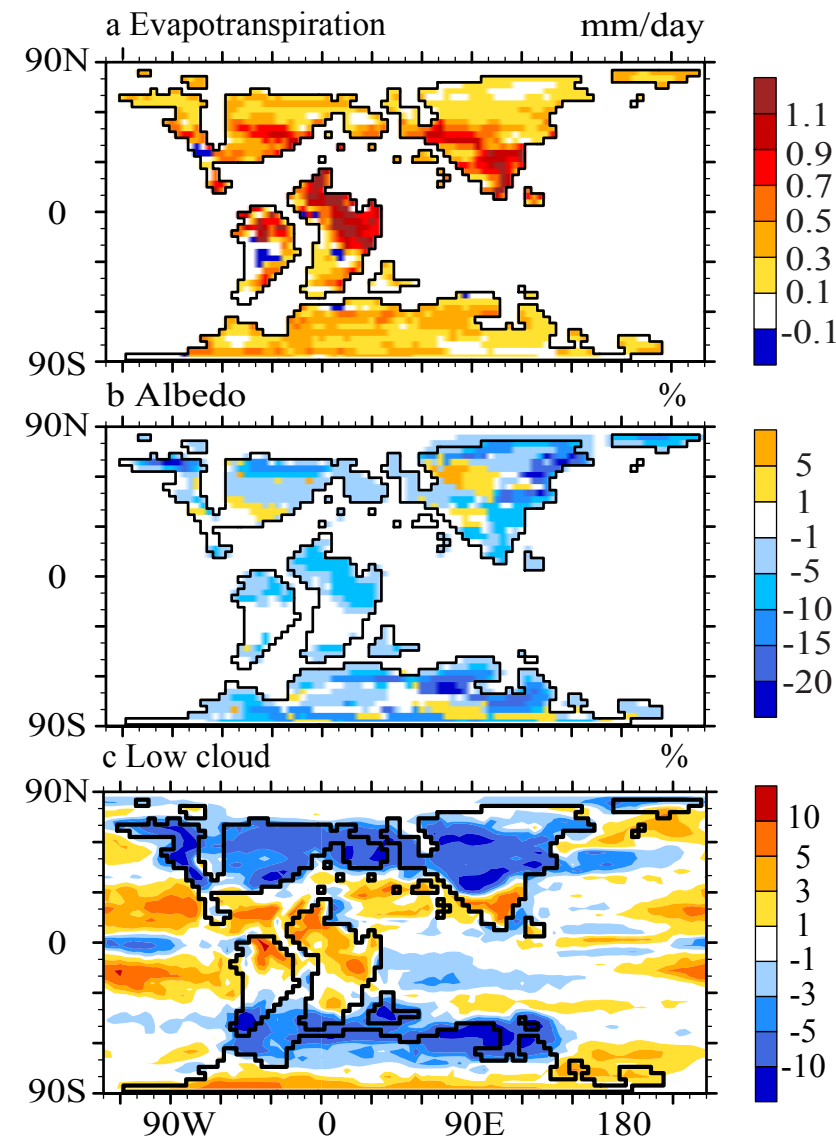

Fig. 6. Annual mean (a) total evapotranspiration over land (mm day $^{-1}$ ); (b) surface albedo (\%); and (c) low cloud cover $(\%)$ for the 10xDGVM-10xBG experiments (\%).

\section{Discussion}

\subsection{The role of vegetation feedbacks under high $\mathrm{CO}_{2}$}

Our results show that vegetation acts to warm high latitudes and cool low latitudes in a warm climate with high $\mathrm{CO}_{2}$, similar to the role of modern vegetation (Bonan, 2008). The simulated warming effect of high-latitude forests on polar regions is also consistent with previous Cretaceous studies (Deconto et al., 2000; Otto-Bliesner and Upchurch, 1997; Upchurch et al., 1998). However, our simulated reduction in high-latitude surface albedo $(\sim 0.06)$ and the associated warming $\left(<2{ }^{\circ} \mathrm{C}\right)$ are more than one-half less than in these studies, mainly because we assess the impact of vegetation in a warm mean climate with little snow $(<0.15)$ and sea ice $(<0.01)$ (Table 3$)$. In contrast, using a atmospheric $\mathrm{CO}_{2}$ value of 580 ppmv, Upchurch et al. (1998) report that snow and sea ice fraction are up to 0.62 and 0.38 , allowing a stronger vegetation-snow-sea ice albedo feedback. The weaker warming here is also linked to the decrease in poleward oceanic heat transport resulting from the weakening of MOC, which is not resolved in the earlier studies. The simulated mean annual temperatures over the Eurasian inte- rior and Arctic Ocean only increase $\sim 2{ }^{\circ} \mathrm{C}$ by vegetation and are up to $10^{\circ} \mathrm{C}$ lower than those estimated by proxies such as leaf physiognomy (Spicer et al., 2002, 2008) and TEX 86 method (Jenkyns et al., 2004). Moreover, as the vegetationinduced warming is most pronounced during the warm late spring-early summer (Fig. 5a), the inclusion of vegetation does not help to reduce high-latitude seasonality. Therefore, we conclude that high-latitude forests can only be considered a secondary mechanism for the mid-Cretaceous polar warmth. Other mechanisms in addition to high atmospheric $\mathrm{CO}_{2}$ and high-latitude vegetation are required to maintain the polar warmth.

We find that $\sim 20-40 \%$ of the increase in surface absorbed solar radiation over high-latitude forests is due to cloud feedbacks. In fact, the increase in cloud radiative forcing surpasses the albedo feedback during late spring and early summer (Fig. 5d, e). This positive cloud feedback contradicts a previous study (Betts, 1999), which reports that the presence of vegetation induced a high-latitude summer cooling of $>2{ }^{\circ} \mathrm{C}$ mainly by reducing surface solar radiation via enhanced cloud cover. These contrasting results highlight the uncertainty of cloud feedbacks in determining the overall effect of high-latitude forests.

\subsection{Oceanic circulation}

Our simulations are consistent with modelling studies with a dynamic ocean component that vegetation can have an important impact on MOC, due to vegetation-induced changes in hydrological cycle and sea surface temperature (Brovkin et al., 2002, 2009; Ganopolski et al., 1998; Lohmann et al., 2006). Moreover, our simulations suggest that the response of MOC to vegetation could exceed that of a tenfold increase in atmospheric $\mathrm{CO}_{2}$ concentration. Proxy records and model studies demonstrate that global vegetation pattern is highly correlated with climate changes during the geological past and future (e.g., Spicer and Chapman, 1990; Alo and Wang, 2008; Cramer et al., 2001). Therefore, vegetation-climate interactions should be taken into account for simulating the MOC response to past and future climate change.

\section{Caveats}

In the absence of global paleovegetation reconstructions, most previous modelling studies of the mid-Cretaceous have assumed a uniform vegetation type on all continents (e.g., Donnadieu et al., 2006; Poulsen et al., 2007; Zhou et al., 2008). In this contribution, we use a dynamic vegetation model to overcome this limitation. We emphasise, though, that the simulation of pre-Quaternary vegetation is subject to uncertainty, mainly due to a paucity of evidence for the construction and physiology of past ecosystems. Due to our lack of understanding of past ecosystems, paleovegetaion modelling relies on a modern understanding of PFTs and their bioclimatic, physiological and dynamic relationships that may not be entirely appropriate for past times. For 

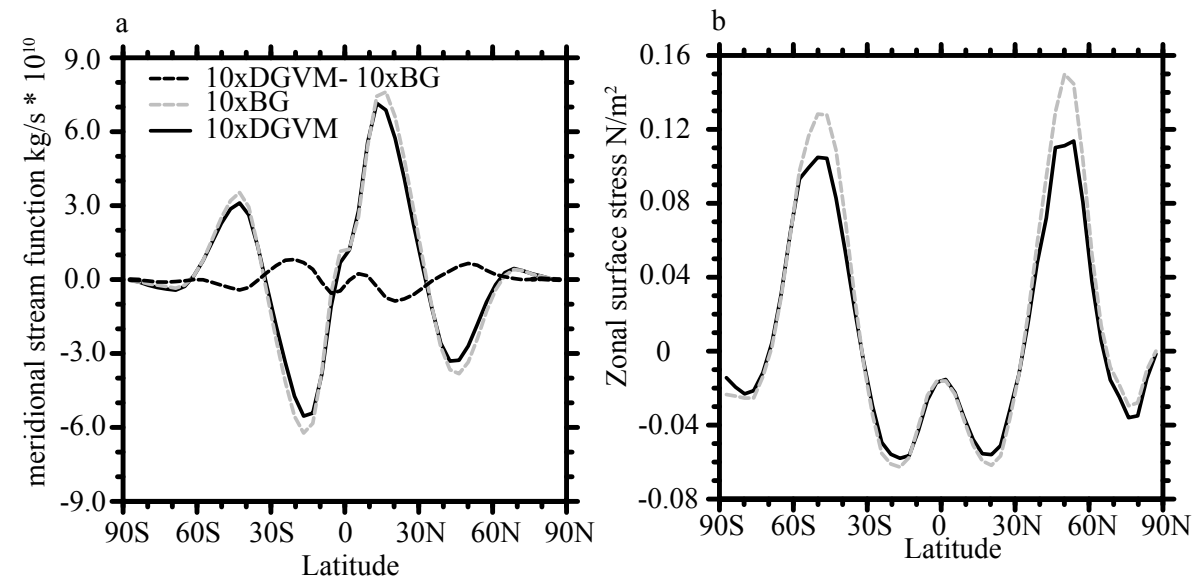

Fig. 7. Zonal-average annual mean meridional streamfunction $\left(10^{10} \mathrm{~kg} \mathrm{~s}^{-1}\right)$ at $400 \mathrm{mb}$ (a); and wind stress $\left(\mathrm{N} \mathrm{m}^{-2}\right)$ over the Pacific Ocean (b) for the 10xDGVM (black solid line), 10xBG (grey dashed line) and 10xDGVM-10xBG experiments (black dashed line), respectively.
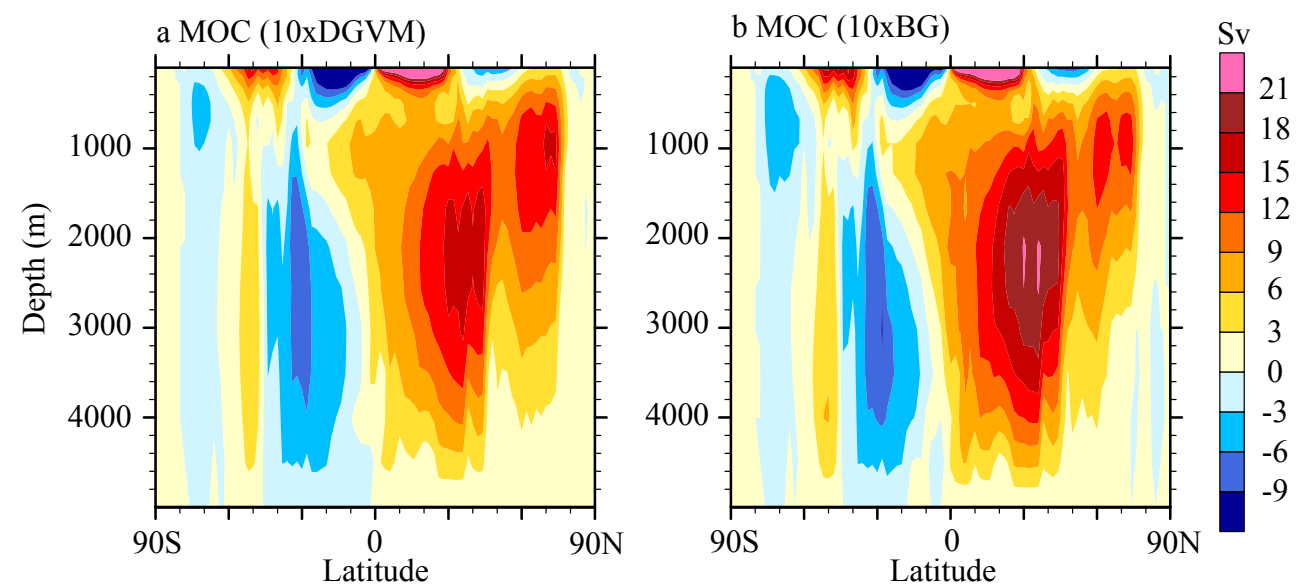

Fig. 8. Annual mean Meridional overturning circulation (Sv) for (a) 10xDGVM experiment; and (b) 10xBG experiment. Positive (in yellow and red) means clockwise flow direction and negative means counterclockwise flow direction.

example, grass, which is a dominant PFT at present, had not evolved in mid-Cretaceous. We keep grass in our simulation because it is the only available herbaceous PFT. Another substantial change between the modern and mid-Cretaceous is angiosperms. The modern angiosperm-dominated tropical forests may not have appeared until the Paleocene (Burnham and Johnson, 2004). Yet our simulations show extensive tropical forests resembling the modern distribution, an overestimation that may be linked to the inclusion of PFTs that represent modern angiosperm trees. Consequently, CLMDVGM may overestimate the impact of low-latitude vegetation on mid-Cretaceous climate, because angiosperms have a much larger impact on hydrology relative to other plants due to their high transpiration capacity (Boyce and Lee, 2010). Another uncertainty in our simulations is the use of modern physiological $p \mathrm{CO}_{2}$ (355 ppmv). Presumably, increasing atmospheric $p \mathrm{CO}_{2}$ could enhance plant growth and reduce plant transpiration. As a result, our model might un- derestimate vegetation productivity and overestimate canopy evapotranspiration. To more accurately simulate the midCretaceous vegetation and its feedbacks, more paleovegetation data is needed to appropriately parameterize the midCretaceous dominant PFTs.

\section{Conclusions}

We investigate the vegetation-climate interaction using a coupled ocean-atmosphere GCM (CCSM3) with a dynamic vegetation component. The model demonstrates a positive feedback between vegetation and polar climate; $\mathrm{CO}_{2}$-induced warming promotes expansion of high-latitude forests, which leads to additional polar warming via reducing surface albedo and low cloud cover. However, the warming effect of vegetation at high latitudes is smaller than reported in previous studies, mainly due to the less pronounced surface albedo feedback in the absence of large snow and sea 
ice cover under the simulated warm mean climate. Over low latitude continents, the feedbacks between vegetation and climate are opposite; forest cover decreases with higher $\mathrm{CO}_{2}$, and the presence of forests leads to year-round cooling. The cooling is associated with enhanced evapotranspiration and low cloud cover.

The simulation of mid-Cretaceous vegetation has unexpected effects on the ocean. First, as a result of the enhanced atmospheric vapour content with vegetation, downwelling longwave radiation increases over ocean, leading to surface warming at sea surface. Second, vegetation alters wind fields, resulting in weakening of wind-driven subtropical and subpolar gyres and poleward displacement of the North Pacific western boundary current. Lastly, the intensified precipitation enhances the freshwater flux into the highlatitude Pacific. This freshening in conjunction with surface warming reduces the meridional overturning circulation in both hemispheres, which reduces meridional heat transport and damps high-latitude warming.

Acknowledgements. We thank Esther C. Brady for her help in setting up the simulations. This study was financially supported by grants (0433440 and 0310032) from the National Science Foundation's Atmospheric Program (to C. Poulsen, D. Pollard and T. White) and the Barbour Scholarship from University of Michigan (to J. Zhou). The CCSM3 mid-Cretaceous simulations were run at the National Center for Atmospheric Research (NCAR).

Edited by: A. Haywood

\section{References}

Abbot, D. S. and Tziperman, E.: A high-latitude convective cloud feedback and equable climates, Q. J. Roy. Meteorol. Soc., 134, 165-185, 2008.

Alo, C. A. and Wang, G.: Potential future changes of the terrestrial ecosystem based on climate projections by eight general circulation models, Geophys. Res. Lett., 113, G01004, doi:10.1029/2007JG000528, 2008.

Barron, E. J.: Cretaceous plate tectonic reconstructions, Palaeogeogr., Palaeocl., 59, 3-29, 1987.

Barron, E. J. and Washington, W. M.: Warm Cretaceous climates: High atmospheric $\mathrm{CO}_{2}$ as a plausible mechanism, in: The carbon cycle and atmospheric $\mathrm{CO}_{2}$ : Natural variations, edited by: Sundquist, E. T. and Broecker, W. S.: Archean to present, American Geophysical Union Geophysical Monograph, 32, 546-553, 1985.

Barron, E. J., Fawcett, P. J., Peterson, W. H., Pollard, D., and Thompson, S. L.: A "simulation" of Mid-Cretaceous climate, Paleoceanography, 10, 953-962, 1995.

Beerling, D. J., Woodward, F. I., and Valdes, P. J.: Global terrestrial productivity in the mid-Cretaceous (100Ma): Model simulations and data, in: Evolution of the Cretaceous ocean-climate system, edited by: Barrera, E. and Johnson, C., Spec. Pap. Geol. Soc. Am., 332, 385-390, 1999.

Betts, R. A.: Self-beneficial effects of vegetation on climate in an ocean-atmosphere general circulation model, Geophys. Res. Lett., 26, 1457-1460, 1999.
Bice, K. L. and Norris, R. D.: Possible atmospheric $\mathrm{CO}_{2}$ extremes of the Middle Cretaceous (late Albian-Turonian), Paleoceanography, 17, 1070, doi:10.1029/2002PA000778, 2002.

Bice, K. L., Huber, B. T., and Norris, R. D.: Extreme polar warmth during the Cretaceous greenhouse? Paradox of the late Turonian $\delta^{18} \mathrm{O}$ record at Deep Sea Drilling Project Site 511, Paleoceanography, 18, 1031, doi:10.1029/2002PA000848, 2003.

Bice, K. L., Birgel, D., Meyers, P. A., Dahl, K. A., Hinrichs, K., and Norris, R. D.: A multiple proxy and model study of Cretaceous upper ocean temperatures and atmospheric $\mathrm{CO}_{2}$ concentrations, Paleoceanography, 21, PA2002, doi:10.1029/2005PA001203, 2006.

Bonan, G. B.: Forests an climate change: forcings, feebacks, and the climate benefits of forests, Science, 320, 1444-1449, 2008.

Bonan, G. and Levis, S.: Evalulating aspects of the Community Land and Atmosphere Models (CLM3 and CAM3) using a dynamic global vegetation model, J. Climate, 19, 2290-2301, 2006.

Bonan, G. B., Levis, S., Sitch, S., Vertenstein, M., and Oleson, K.: A dynamic global vegetation model for use with climate models: concepts and description of simulated vegetation dynamics, Glob. Change Biol., 9, 1543-1566, 2003.

Boyce, C. K. and Lee, J. E.: An exceptional role for flowering plant physiology in the expansion of tropical rainforests and biodiversity, Proc. Roy. Soc. Lond., Ser. B, Biol. Sci., 277, 3437-3443, 2010.

Branstetter, M. L.: Development of a parallel river transport algorithm and applications to climate studies, Ph.D. thesis, University of Texas at Austin, 119 pp., 2001.

Brovkin, V.: Climate-vegetation interaction, J. Phys. IV FRANCE, 12, 10-57, 2002.

Brovkin, V., Raddatz, T., Reich, C. H., Claussen, M., and Gayler, V.: Global biogeophysical interactions between forest and climate, Geophys. Res. Lett., 36, L07405, doi:10.1029/2009GL037543, 2009.

Burnham, R. J. and Johnson, K. R.: South American palaeobotany and the origins of neotropical rainforests, Phil. Trans. R. Soc. Lond. B, 359, 1595-1610, 2004.

Cerling, T. E., Wang, Y., and Quade, J.: Expansion of $\mathrm{C}_{4}$ ecosystems as an indicator of global ecological change in late Miocene, Nature, 361, 344-345, 1993.

Collins, W. D., Bitz, C. M., Blackmon, M. L., Bonan, G. B., Bretherton, C. S., Carton, J. A., Chang, P., Doney, S. C., Hack, J. J., Henderson, T. B., Kiehl, J. T., Large, W. G., McKenna, D. S., Santer, B. D., and Smith, R. D.: The Community Climate System Model Version 3 (CCSM3), J. Climate, 19, 2122-2143, 2006.

Covey, C. and Barron, E.: The role of ocean heat transport in climatic change, Earth-Sci. Rev., 21, 429-445, 1988.

Cramer, W., Bondeau, A., Woodward, F. I., Prentice, I. C., Betts, R. A., Brovkin, V., Cox, P., Fisher, V., Foley, J. A., Friend, A. D., Kucharik, C., Lomas, M., Ramankutty, N., Sitch, S., Smith, B., White, A., and Young-Molling, C.: Global response of terrestrial ecosystem structure and function to $\mathrm{CO}_{2}$ and climate change: results from six dynamic global vegetation models, Glob. Change Biol., 7, 357-373, 2001.

Donnadieu, Y., Pierrehumbert, R., Jacob, R., and Fluteau, F.: Modelling the primary control of paleogeography on Cretaceous climate, Earth Planet. Sci. Lett., 248, 426-437, 2006.

Donnadieu, Y., Goddéris, Y., and Bouttes, N.: Exploring the climatic impact of the continental vegetation on the Mezosoic 
atmospheric $\mathrm{CO}_{2}$ and climate history, Clim. Past, 5, 85-96, doi:10.5194/cp-5-85-2009, 2009.

DeConto, R. M., Brady, E. C., Bergengren, J., and Hay, H. H.: Late Cretaceous Climate, Vegetation, and Ocean Interactions, in: Warm Climates in Earth History, edited by: Huber, B., MacLeod, K. G., and Wing, S. L., Cambridge University Press, 275-297, 2000.

Dino, R., Pocknall, D. T., and Dettmann, M. E.: Morphology and ultrastructure of elater-bearing pollen from the Albian to Cenomanian of Brazil and Ecuador: implications for botanical affinity, Rev. Palaeobot. Palyno., 105, 201-235, 1999.

Farrel, G. F.: Equable climate dynamics, J. Atmos. Sci., 47, 2986 2995, 1990.

Falcon-Lang, H. J., Cantrill, D. J., and Nichols, G. J.: Biodiversity and terrestrial ecology of a mid-Cretaceous, high-latitude floodplain, Alexander Island, Antarctica, J. Geol. Soc., 158, 709-724, 2001

Ganopolski, A., Kubatzki, C., Claussen, M., Brovkin, V., and Petoukhov, V.: The influence of vegetation-atmosphere-ocean interaction on climate during the mid-Holocene, Science, 280, 1916-1919, 1998.

Gough, D. O.: Solar interior structure and luminosity variations, Sol. Phys., 74, 21-34, 1981.

Herman, A. B. and Spicer, R. A.: Palaeobotanical evidence for a warm Cretaceous Arctic Ocean, Nature, 380, 330-333, 1996.

Jacobs, B. F., Kingston, J. D., and Jacobs, L. L.: The origin of grass-dominanted ecosystems, Ann. Missouri Bot. GARD., 86, 590-643, 1999.

Jenkyns, H. C., Forster, A., Schouten, S., and Damsté, J. S. S.: High temperatures in the Late Cretaceous Arctic Ocean, Nature, 432, 888-892, 2004.

Kiehl, J. T. and Shields, C. A.: Climate simulation of the latest Permian: implications for mass extinction, Geology, 33, 757760, 2005.

Körner, C.: Ecological impacts of atmospheric $\mathrm{CO}_{2}$ enrichment on terrestrial ecosystems, Philos. T. Roy. Soc. Lond., 361, 20232041, 2003.

Korty, R. L., Emanuel, K. A., and Scott, A. J.: Tropical cycloneinduced upper-ocean mixing and climate: application to equable climate, J. Climate, 21, 638-654, 2008.

Kump, L. R. and Pollard, D.: Amplification of Cretaceous warmth by biological cloud feedbacks, Science, 320, 195, doi:10.1126/science.1153883, 2008.

Levis, S., Bonan, G. B., Vertenstein, M., and Oleson, K. W.: The Community Land Model's dynamic global vegetation model (CLM-DGVM): Technical description and user's guide, NCAR Tech. Note TN-459_IA, 50 pp., 2004.

Lohmann, G., Butzin, M., Micheels, A., Bickert, T., and Mosbrugger, V.: Effect of vegetation on the Late Miocene ocean circulation, Clim. Past Discuss., 2, 605-631, doi:10.5194/cpd-2-6052006, 2006.

Otto-Bliesner, B. L. and Upchurch Jr., G. R.: Vegetation-induced warming of high-latitude regions during the Late Cretaceous period, Nature, 385, 804-807, 1997.

Otto-Bliesner, B. L., Brady, E. C., and Shields, C.: Late Cretaceous ocean: Coupled simulations with the National Center for Atmospheric Research Climate System Model, J. Geophys. Res., 107, 4019, doi:10.1029/2001JD000821, 2002.
Peng, C. H.: From static biogeographical model to dynamic global vegetation model: a global perspective on modelling vegetation dynamics, Ecol. Modell., 135, 33-54, 2000.

Price, G. D., Valdes, P. J., and Sellwood, B. W.: Quantitative palaeoclimate GCM validation: Late Jurassic and mid-Cretaceous case studies, J. Geol. Soc., 154, 769-772, 1997.

Poulsen, C. J.: A balmy Arctic, Nature, 432, 814-815, 2004.

Poulsen, C. J., Barron, E. J., and Peterson, W. H.: A reinterpretation of mid-Cretaceous shallow marine temperatures through modeldata comparison, Paleoceanography, 14, 679-697, 1999.

Poulsen, C. J., Gendaszek, A. S., and Jacob, R. L.: Did the rifting of the Atlantic Ocean cause the Cretaceous thermal maximum? Geology, 31, 115-118, 2003.

Poulsen, C. J., Pollard, D., and White, T. S.: General circulation model simulation of the $\delta^{18} \mathrm{O}$ content of continental precipitation in the middle Cretaceous: A model-proxy comparison, Geology, 35, 199-202, 2007.

Scotese, C. R.: Times of global plate tectonic reorganization and their causes [abs]: Earth system processes, Programmes with Abstracts: London, Geological Society of London and Geological Society of America, p. 102, 2001.

Schlesinger, W. H.: Biogeochemistry: An analysis of global change 2nd end, Academic Press, San Diego, 1997.

Sloan, L. C. and Pollard, D.: Polar Stratospheric clouds: A high latitude warming mechanism in an ancient greenhouse world, Geophys. Res. Lett., 25, 3517-3520, 1998.

Spicer, R. A. and Chapman, J. L.: Climate change and the evolution of high-latitude terrestrial vegetation and floras. TREE, 5, 279284, 1990.

Spicer, R. A. and Parrish, J. T.: Paleobotanical evidence for cool north polar climates in middle Cretaceous (Albian-Cenomanian) time, Geology, 14, 703-706, 1986.

Spicer, R. A., Rees, P. M., and Chapman, J. L.: Cretaceous phytogeography and climate signals, Philos. T. Roy. Soc. B, 341, 277-286, 1993.

Spicer, R. A., Ahlberg, A., Herman, A. B., Kelley, S. P., Raikevich, M. I., and Rees, P. M.: Palaeoenvironment and ecology of the middle Cretaceous Grebenka flora of northeastern Asia, Palaeogeogr. Palaeocl., 184, 65-105, 2002.

Spicer, R. A., Ahlberg, A., Herman, A. B., Hofmann, C., Raikevich, M., Valdes, P. J. and Markwich, P., J.: The Late Cretaceous continental interior of Siberia: a challenge for climate models, Earth Planet. Sci. Lett., 267, 228-235, 2008.

Upchurch Jr., G. R., Otto-Bliesner, B. L., and Scotese, C. Vegetation-atmosphere interactions and their role in global warming during the latest Cretaceous, Philos. T. Roy. Soc. B, 353, 97-112, 1998.

Yeager, S. G., Shields, C. A., Large, W. G., and Hack, J. J.: The low-resolution CCSM3, J. Climate, 19, 2545-2566, 2006.

Ziegler, A. M., Eshel, G., Rees, P. M., Rothfus, T. A., Rowley, D. B., and Sunderlin, D.: Tracing the tropics across land and sea: Permian to present, Lethaia, 36, 227-254, 2003.

Zhou, J., Poulsen, C. J., Pollard, D., and White, T. S.: Simulation of modern and middle Cretaceous marine $\delta^{18} \mathrm{O}$ with an ocean-atmosphere general circulation model, Paleoceanography, 23, PA3223, doi:10.1029/2008PA001596, 2008. 